\title{
Absence of Mycobacterium avium subsp. paratuberculosis in the microdissected granulomas of Crohn's disease
}

\author{
Fabien K Baksh ${ }^{1}$, Sydney D Finkelstein ${ }^{2}$, Shashi M Ariyanayagam-Baksh ${ }^{1}$, \\ Patricia A Swalsky ${ }^{2}$, Edwin C Klein ${ }^{3}$ and Jean C Dunn ${ }^{2}$ \\ ${ }^{1}$ Department of Pathology, Lancaster General Hospital, Lancaster, PA, USA; ${ }^{2}$ Department of Pathology and \\ ${ }^{3}$ Division of Laboratory Animal Resources, University of Pittsburgh, PA, USA
}

\begin{abstract}
The etiology of Crohn's disease remains unknown with inflammatory, infectious, and/or genetic causes suspected. Granulomatous inflammation is a characteristic feature of the disorder, resembling the tissue response to mycobacterium. Mycobacterium avium subsp. paratuberculosis (MAP) is the causative agent in Johne's disease, a chronic ulcerative intestinal condition in cattle, and has been implicated as a likely candidate. We carefully microdissected the granulomas from the paraffin-embedded resection specimens of 18 patients with well-established Crohn's disease. The DNA obtained was PCR amplified for the IS900 and IS1311 repeat elements of MAP, PCR product size maintained at 101 and 124 base pairs, respectively. Archival tissue from bovine Johne's disease was used as a positive control. MAP-specific DNA, confirmed by sequencing and comparison with prototype strain sequence, was appropriately amplified from the positive control. None of the Crohn's disease cases yielded a positive amplification product, failing to support a role for the organism in the pathogenesis of this illness.

Modern Pathology (2004) 17, 1289-1294, advance online publication, 21 May 2004; doi:10.1038/modpathol.3800184
\end{abstract}

Keywords: Crohn's disease; granulomas; Mycobacteria; M. paratuberculosis; M. avium

Crohn's disease is a chronic idiopathic inflammatory disease that can involve any region of the gastrointestinal tract from the mouth to the anus. The etiology of this disorder is unknown, with genetic, immunologic, and infectious factors implicated. An increased prevalence in first-degree relatives and monozygotic twins of affected patients suggests a genetic predisposition. An inciting factor (presumably environmental) may then result in an abnormal, sustained immunologic response in the patient. Alternatively, genetically predetermined abnormalities in the gastrointestinal tract may predispose to increased susceptibility to infectious or toxic damage.

Histologically, Crohn's disease is characterized by skip lesions and transmural inflammation, with a

Correspondence: Dr FK Baksh, MD, Department of Pathology, Lancaster General Hospital, PO Box 3555, 555 N Duke St, Lancaster, PA 17604-3555, USA.

E-mail: fkbaksh@lancastergeneral.org

This study was presented at The United States and Canadian Academy of Pathology 89th Annual Meeting, New Orleans, LA, March 2000.

Received 30 October 2003; revised 12 April 2004; accepted 26 April 2004; published online 21 May 2004 characteristic though not obligate feature of the disease being granuloma formation. It bears a clinicopathologic resemblance to Johne's disease, a chronic ulcerative intestinal disease in cattle, for which the etiologic agent is known to be M. avium subsp. paratuberculosis (MAP). This resemblance and the presence of granulomas in Crohn's disease, has made MAP a putative etiologic agent, although the intestine in Johne's disease admittedly contains millions of mycobacteria as opposed to Crohn's disease.

Numerous authors have explored the link between MAP and Crohn's disease using various methods on biopsies, resections, fresh, frozen, and paraffin-embedded tissue, with variable results. ${ }^{1-19}$ However, if MAP and Crohn's disease are etiologically related, then intuitively the granulomas that are characteristic of the latter should harbor the organism. Indeed, some authors have associated the ability to identify MAP DNA with the presence of granulomas, ${ }^{1,2}$ while others have not. $^{3}$ To address this issue, we sought to identify specific MAP sequences from carefully microdissected granulomas in patients with well-characterized Crohn's disease using a PCRbased technique. 


\section{Materials and methods}

Pathology reports from the MARS archival system of the University of Pittsburgh Medical Center (Presbyterian and Shadyside hospitals) were searched using the keywords 'Crohn's disease' and 'granulomas'. The resulting reports were examined and only resection specimens submitted with the clinical diagnosis of Crohn's disease, and reported to contain granulomas were further studied. The H\&E slides of these cases were then reviewed along with the clinical and radiologic reports from the medical records. One case with probable Yersinia enterocolitis, three cases of ulcerative colitis with mucin granulomas, and cases of Crohn's disease with small and scattered granulomas were excluded. Paraffin blocks were unavailable in two additional cases, and recut sections for microdissection contained no granulomas in another two. A total of 18 cases were then available for study.

Microscopic foci of granulomas were microdissected from multiple $4 \mu \mathrm{m}$ thick histologic sections under stereoscopic observation, so as to provide sufficient tissue for amplification, with minimal contamination by surrounding nongranulomatous material. The samples were then treated with $50 \mu \mathrm{l}$ of Proteinase $\mathrm{K}(10 \mathrm{mg} / \mathrm{ml})$ for $2 \mathrm{~h}$ and boiled for 5 min to remove enzyme activity. The DNA obtained was then PCR amplified using two separate reactions, each targeted at distinct repeat elements in the MAP genome (IS900 and IS1311). PCR amplification was performed in a routine manner according to the manufacturer's instructions (GeneAMP, Applied Biosystems) with cycling parameters of denaturation, annealing and polymerization being $95^{\circ} \mathrm{C}$ ( $1 \mathrm{~min}), 55^{\circ} \mathrm{C}(1 \mathrm{~min})$ and $72^{\circ} \mathrm{C}(2 \mathrm{~min})$ for 40 cycles. The IS900 insertion element is specific for this organism, and the primers used were 5'-GGAGC GATTTCGCCGCCA-3' (upstream), and 5'-GTCG GCGGAGGCGAATGC-3' (downstream). The IS1311 element is also present in Mycobacterium avium, and the primers were 5'-GCCGGTCCGCATGA ACGG-3' (upstream), and 5'-GGAATCCGCAACTC CAAATC- $3^{\prime}$ (downstream). PCR product lengths were maintained at 124 and $101 \mathrm{bp}$, respectively to ensure sensitive detection from the archival material. A BLAST search was performed on all primer sequences as well as sequenced amplified PCR products to confirm the specificity of the primers.

Archival tissue from bovine Johne's disease was used as a positive control, with the microdissected mucosa similar in size to the granulomas of the Crohn's disease cases. Intentional dilution of control with normal tissue (25\% Johne's:75\% normal), was also performed. The normal tissue was obtained from sections of grossly unremarkable areas of the same case, with no histological evidence of inflammation, nor evidence of organisms using a ZiehlNeelsen stain. To confirm the integrity of the DNA from the archival tissue, the k-ras gene was PCR amplified in all cases.

Products of nucleic acid amplification were electrophoresed in a $4 \%$ agarose gel and visualized by ethidium bromide staining. The amplicons generating strong signals were sequenced using dideoxy chain termination sequencing carried out according to the manufacturer's instructions (Sequenase, United States Biochemical Corp., Cleveland, $\mathrm{OH}, \mathrm{USA})$.

\section{Results}

The clinicopathologic data of the 18 patients are shown in Table 1. All patients were diagnosed with Crohn's disease using clinical, endoscopic, and pathologic criteria. Each case showed a transmural lymphoplasmacytic infiltrate, skip lesions, and was noteworthy for the presence of numerous noncaseating epithelioid granulomas (Figure 1a). These were variably present in the small intestinal wall $(n=7)$, colonic wall $(n=7)$, draining lymph nodes $(n=8)$, and ovary $(n=1)$, for a total of 23 sites from the 18 patients. In each case, the granulomas were carefully microdissected to limit contamination by adjacent tissue (Figure 1b).

MAP-specific DNA from both IS900 and IS1311 insertion sequences was appropriately identified from control (including diluted) tissue, confirmed by DNA sequencing and comparison with prototype strain sequences (GenBank numbers X16293 and AJ223975, respectively). All cases of human Crohn's disease failed to yield a positive amplification product for either the IS900 (Figure 2), or IS1311 sequences.

Table 1 Clinicopathologic data for Crohn's disease patients

\begin{tabular}{|c|c|c|c|c|}
\hline Case \# & $\operatorname{Sex}$ & Age & Site of Crohn's disease & Site of granulomas \\
\hline 1 & $\mathrm{~F}$ & 33 & Colon & Lymph node \\
\hline 2 & $\mathrm{~F}$ & 19 & Terminal ileum/cecum & $\begin{array}{l}\text { Terminal ileum } \\
\text { Lymph node }\end{array}$ \\
\hline 3 & $\mathrm{~F}$ & 53 & Left colon & $\begin{array}{l}\text { Left colon } \\
\text { Lymph node }\end{array}$ \\
\hline 4 & $\mathrm{M}$ & 38 & Colon & Colon \\
\hline 5 & $\mathrm{~F}$ & 28 & Sigmoid colon & $\begin{array}{l}\text { Sigmoid colon } \\
\text { Lymph node }\end{array}$ \\
\hline 6 & $\mathrm{~F}$ & 80 & Right colon & $\begin{array}{l}\text { Lymph node } \\
\text { Ovary }\end{array}$ \\
\hline 7 & $\mathrm{~F}$ & 29 & Small intestine & Small intestine \\
\hline 8 & $\mathrm{~F}$ & 65 & Sigmoid/rectum & Sigmoid colon \\
\hline 9 & M & 26 & Terminal ileum/cecum & $\begin{array}{l}\text { Terminal ileum } \\
\text { Lymph node }\end{array}$ \\
\hline 10 & $\mathrm{M}$ & 27 & Small intestine & Small intestine \\
\hline 11 & $\mathrm{~F}$ & 42 & Colon & Colon \\
\hline 12 & $\mathrm{~F}$ & 34 & Terminal ileum & Terminal ileum \\
\hline 13 & $\mathrm{~F}$ & 27 & Terminal ileum/cecum & Lymph node \\
\hline 14 & $\mathrm{~F}$ & 27 & Sigmoid colon & Sigmoid colon \\
\hline 15 & $\mathrm{~F}$ & 18 & Terminal ileum/cecum & Terminal ileum \\
\hline 16 & $\mathrm{M}$ & 25 & Colon & Colon \\
\hline 17 & $\mathrm{M}$ & 46 & Small intestine & Small intestine \\
\hline 18 & M & 32 & Terminal ileum/cecum & Lymph node \\
\hline
\end{tabular}



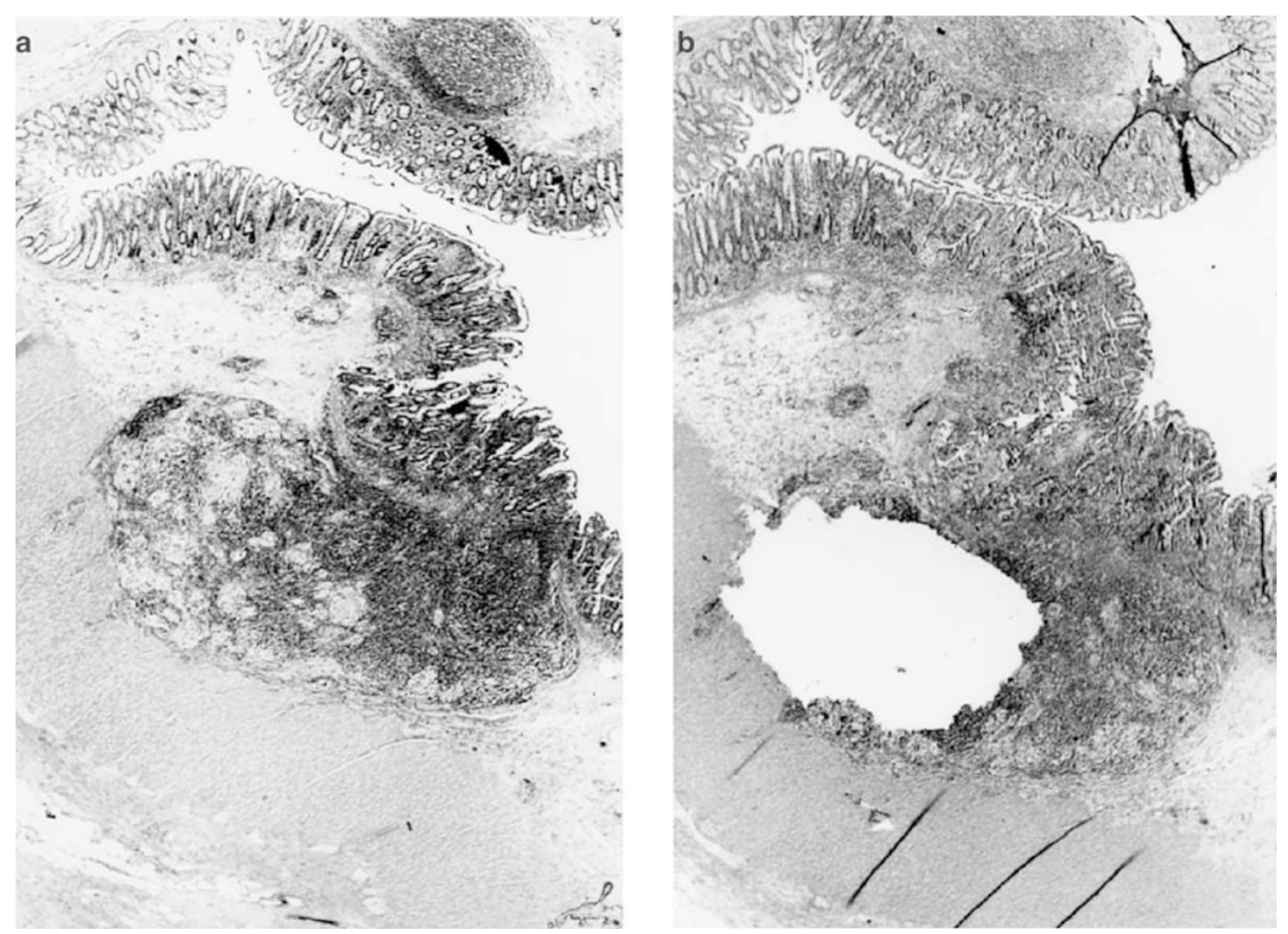

Figure 1 Case 4 showing a well-formed noncaseating submucosal granuloma. (a) Before, and (b) after microdissection (H\&E $\times 40)$

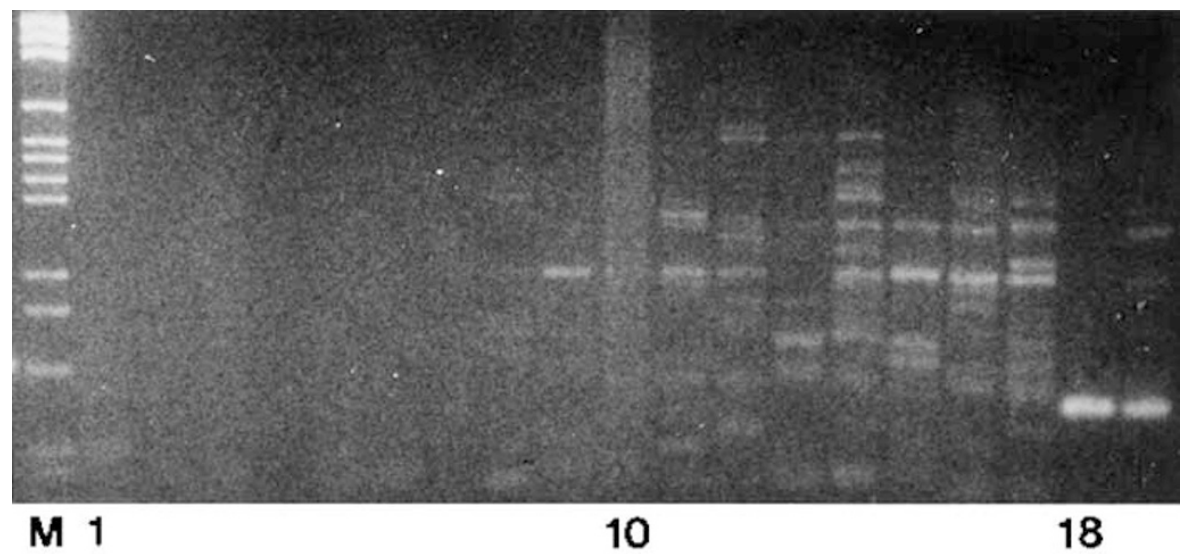

Figure 2 PCR gel of products obtained using IS900 (M. avium subsp. paratuberculosis specific) primers. M-control markers; lanes 117-Crohn's disease with absent or nonspecific amplification bands consistent with absence of amplifiable $M$. avium subsp. paratuberculosis DNA; lane 18-undiluted Johne's disease; lane 19—diluted Johne’s disease (25\% Johne’s, 75\% normal).

BLAST searches performed on the four primer sequences and Johne's disease sequenced products all showed exact matches with MPT (IS900 and IS1311 primers and product), and Mycobacterium avium (IS1311 primers and product). No other organism showed an exact match, confirming the specificity of the primers and PCR product. All cases showed an appropriate amplification product for the k-ras gene.

\section{Discussion}

The underlying premise of our study is that if MAP is etiologically linked to Crohn's disease, then the granulomas characteristic of the latter should harbor the organism, in a similar manner to tuberculosis. Indeed, the very presence of these granulomas is a feature that makes the organism an attractive causative agent. We thus used the approach of 
carefully microdissecting the granulomas from patients with Crohn's disease, thus allowing us to concentrate any organisms that may be present, and limit contamination with nongranulomatous tissue.

Our study failed to amplify DNA from the IS900 sequence that is specific to MAP. ${ }^{20}$ We also used an insertion sequence common to both MAP and Mycobacterium avium, ${ }^{21}$ again with a negative result. Our positive control case of Johne's disease showed strong amplification products for both sets of primers. We intentionally diluted the control using $75 \%$ normal tissue and still obtained a strong product intensity. The genetic similarity between MAP strains isolated from Crohn's disease and Johne's disease ${ }^{22}$ supports the use of the latter as a positive control in this study. The use of paraffinembedded tissue in the control sample also verifies that our technique can identify DNA from archival material.

We identified one published study ${ }^{18}$ that has used a similar approach to ours, with the only major apparent difference being the use of a nested-PCR method. They found six of 15 cases positive for the IS900 gene while none of 12 control granulomas. This is in direct contrast to our results. Perhaps their nested-PCR method provided increased sensitivity, but using our methods, we have been able to sequence viral DNA from paraffin-embedded needle biopsies without histologically and immunohistochemically detectable viral inclusions, ${ }^{23}$ supporting our ability to detect even clinically insignificant levels of microorganisms. Conversely, increased sensitivity may lead to amplification of nonspecifically present organisms in contaminating lymphocytes or other cells as discussed below. Certainly, microdissection limits this contamination but does not completely exclude it, with the significance of this factor increasing with increasing sensitivity of the PCR reaction. Ryan et $a 1^{18}$ also examined the effect of the length of the PCR product, as DNA fragmentation from formalin fixation can prevent amplification of long segments. They used $155 \mathrm{bp}$ and found this to be reliable. We used even shorter amplicons at 121 and $101 \mathrm{bp}$ lengths, to maximize our detection rate.

Many other studies have used PCR-based methods to investigate the same association, with no MAP identified in many, including those using nestedPCR reactions. ${ }^{4,6,7,9,15,16,19}$ Other authors have found a variable number of cases, up to $100 \%$, to harbor the organism. ${ }^{1,3,5,8,10-14,18}$ Several reasons may be responsible for the variability in these results. Differences in patient cohorts, techniques, and experimental conditions immediately come to mind. The use of biopsy material for study (as opposed to resection specimens) would result in an increased likelihood of inclusion of non-Crohn's disease patients in any study of this disorder, as there is significant overlap in the histologic features of this and other disorders on superficial mucosal biopsy. ${ }^{24}$
Additionally, fresh specimens, although more amenable to DNA extraction for PCR than paraffinembedded material, have a distinct disadvantage in that no histologic correlate is available to determine the nature of the tissue under study (such as granulomatous vs nongranulomatous; inflamed vs noninflamed). Thus, different types of tissues are potentially being compared possibly leading to differing results. Our study attempted to limit these factors by using only resection specimens, and histologically confirmed microdissected granulomas.

Ulcerative colitis and control patients have also been found to be positive for MAP. ${ }^{3,7,8,10-14}$ Thus, the finding of MAP DNA in Crohn's disease, including in paraffin-embedded resection specimens, ${ }^{1,12}$ still leaves unanswered the question of whether the organism may be environmentally acquired and nonspecifically present. MAP has been cultured from municipal water supplies ${ }^{11}$ and pasteurized milk, ${ }^{25,26}$ suggesting that it may be ubiquitously present in the environment. Thus, the use of fresh specimens and entire sections of paraffin-embedded tissue may include organisms from the gut lumen as well as those transiently present in the tissue, producing false-positive results. Another theory is that the immune dysregulation and altered milieu present in Crohn's disease patients makes them more susceptible to secondary infection, including by MAP. This may explain the reported increased detection of MAP in these patients compared to ulcerative colitis and control patients. ${ }^{2,8,10-14}$

The possibility also exists that Crohn's disease is a heterogenous group of diseases, with MAP being one etiologic agent. If this were so, then the conflicting results in the literature could be explained by the inclusion of varying proportions of cases actually caused by MAP. One would however expect cases with granulomas to be associated with the organism. This has been suggested in some studies $^{1,2}$ but not others. ${ }^{3}$ These studies did not however specifically target the granulomas as we did. The use of in situ hybridization has detected MAP DNA in myofibroblasts and macrophages of patients with Crohn's disease containing granulomas. ${ }^{2}$ This was found more frequently than in ulcerative colitis, control, and Crohn's patients with no granulomas. Interestingly enough however, no signals were identified in the granulomas themselves, again suggesting that the organism may be secondarily present.

Approaches using antibody titers have shown conflicting results, with statistically significant elevated antibody titers found by some authors, ${ }^{27-31}$ but not others. ${ }^{32}$ From a clinical standpoint, a double-blinded randomized control trial has found no benefit from antituberculous chemotherapy in 130 Crohn's disease patients after 2 and 5 years follow-up. ${ }^{33,34}$ It is thus clear that MAP as an etiological agent in Crohn's disease still remains controversial. 
In conclusion, our inability to identify DNA of the IS900 and IS1311 sequences from the carefully microdissected granulomas of well-characterized cases of Crohn's disease, fails to support a role for $M$. avium subsp. paratuberculosis in the pathogenesis of this disorder.

\section{References}

1 Fidler HM, Thurell W, Johnson NM, et al. Specific detection of Mycobacterium paratuberculosis DNA associated with granulomatous tissue in Crohn's disease. Gut 1994;35:506-510.

2 Hulten K, El-Zimaity HM, Karttunen TJ, et al. Detection of Mycobacterium avium subsp. paratuberculosis in Crohn's diseased tissues by in situ hybridization. Am J Gastroenterol 2001;96:1529-1535.

3 Gan H, Ouyang Q, Bu H. Mycobacterium paratuberculosis in the intestine of patients with Crohn's disease. Chung Hua Nei Ko Tsa Chih 1997;36:228-230.

4 Riggio MP, Gibson J, Lennon A, et al. Search for Mycobacterium paratuberculosis DNA in orofacial granulomatosis and oral Crohn's disease. Gut 1997;41:646-650.

5 Clarkston WK, Presti ME, Petersen PF, et al. Role of Mycobacterium paratuberculosis in Crohn's disease-a prospective, controlled study using polymerase chain reaction. Dis Colon Rectum 1998;41:195-199.

6 Dumonceau JM, Van Gossum A, Adler M, et al. No Mycobacterium paratuberculosis found in Crohn's disease using the polymerase chain reaction. Dig Dis Sci 1996;41:421-426.

7 Rowbotham DS, Mapstone NP, Trejdosiewicz LK, et al. Mycobacterium paratuberculosis DNA not detected in Crohn's disease tissue by fluorescent polymerase chain reaction. Gut 1995;37:660-667.

8 Murray A, Oliaro J, Schlup MMT, et al. Mycobacterium paratuberculosis and inflammatory bowel disease: frequency distribution in serial colonoscopic biopsies using the polymerase chain reaction. Microbios 1995;83:217-228.

9 Kanazawa K, Haga Y, Funakosi O, et al. Absence of Mycobacterium paratuberculosis DNA in intestinal tissues from Crohn's disease by nested polymerase chain reaction. J Gastroenterol 1999;34:200-206.

10 Suenaga K, Yokoyama Y, Okazaki K, et al. Mycobacteria in the intestine of Japanese patients with inflammatory bowel disease. Am J Gastroenterol 1995;90: 76-80.

11 Mishina D, Katsel P, Brown ST, et al. On the etiology of Crohn's disease. Proc Natl Acad Sci USA 1996;93: 9816-9820.

12 Lisby G, Andersen J, Engbaek K, et al. Mycobacterium paratuberculosis in intestinal tissue from patients with Crohn's disease demonstrated by a nested primer polymerase chain reaction. Scand J Gastroenterol 1994;29:923-929.

13 Dell'Isola B, Poyart C, Goulet O, et al. Detection of Mycobacterium paratuberculosis by polymerase chain reaction in children with Crohn's disease. J Infect Dis 1994;169:449-451.

14 Sanderson JD, Moss MT, Tizard MLV, et al. Mycobacterium paratuberculosis DNA in Crohn's disease tissue. Gut 1992;33:890-896.
15 Chiba M, Fukushima T, Horie Y, et al. No Mycobacterium paratuberculosis detected in intestinal tissue, including Peyer's patches and lymph follicles, of Crohn's disease. J Gastroenterol 1998;33:482-487.

16 Frank TS, Cook SM. Analysis of paraffin sections of Crohn's disease for Mycobacterium paratuberculosis using polymerase chain reaction. Mod Pathol 1996;9:32-35.

17 Tiveljung A, Soderholm JD, Olaison G, et al. Presence of eubacteria in biopsies from Crohn's disease inflammatory lesions as determined by $16 \mathrm{~S}$ rRNA gene-based PCR. J Med Microbiol 1999;48:263-268.

18 Ryan P, Bennett MW, Aarons S, et al. PCR detection of Mycobacterium paratuberculosis in Crohn's disease granulomas isolated by laser capture microdissection. Gut 2002;51:665-670.

19 Al-Shamali M, Khan I, Al-Nakib B, et al. A multiplex polymerase chain reaction assay for the detection of Mycobacterium paratuberculosis DNA in Crohn's disease tissue. Scand J Gastroenterol 1997;32: 819-823.

20 Green EP, Tizard MLV, Moss MT, et al. Sequence and characteristics of IS900, an insertion element identified in a human Crohn's disease isolate of Mycobacterium paratuberculosis. Nucl Acid Res 1989;17: 9063-9073.

21 Whittington R, Marsh I, Choy E, et al. Polymorphisms in IS1311, an insertion sequence common to Mycobacterium avium and $M$. avium subsp. paratuberculosis, can be used to distinguish between and within these species. Mol Cel Probes 1998;12:349-358.

22 Francois B, Krishnamoorthy R, Elion J. Comparative study of Mycobacterium paratuberculosis strains isolated from Crohn's disease and Johne's disease using restriction fragment length polymorphism and arbitrarily primed polymerase chain reaction. Epidemiol Infect 1997;118:227-233.

23 Baksh FK, Finkelstein SD, Swalsky PA, et al. Molecular genotyping of BK and JC viruses in human polyoma virus associated interstitial nephritis after renal transplantation. Am J Kid Dis 2001;38: 354-365.

24 Fenoglio-Preiser CM. Inflammatory bowel disease. In: Fenoglio-Preiser CM, Noffsinger AE, Stemmermann GN, Lantz PE, Listrom MB, Rilke FO (eds). Gastrointestinal Pathology-an Atlas and Text, 2nd edn. Lippincott-Raven: Philadelphia, PA, 1999, pp 631-716.

25 Bradbury J. Need we add milk to the list of worrying foods? Lancet 1998;352:549.

26 Corti S, Stephan R. Detection of Mycobacterium avium subsp. paratuberculosis specific IS900 insertion sequences in bulk-tank milk samples obtained from different regions throughout Switzerland. BMC Microbiol 2002;2:15.

27 Suenaga K, Yokoyama Y, Nishimori I, et al. Serum antibodies to Mycobacterium paratuberculosis in patients with Crohn's disease. Dig Dis Sci 1999;44: 1202-1207.

28 El-Zaartari FA, Naser SA, Hulten K, et al. Characterization of Mycobacterium paratuberculosis p36 antigen and its seroreactivities in Crohn's disease. Curr Microbiol 1999;39:115-119.

29 Naser SA, Hulten K, Shafran I, et al. Specific seroreactivity of Crohn's disease patients against p35 and p36 antigens of $M$. avium subsp. paratuberculosis. Vet Microbiol 2000;77:497-504. 
30 Olsen I, Wiker HG, Johnson E, et al. Elevated antibody responses in patients with Crohn's disease against a 14-kDa secreted protein purified from Mycobacterium avium subsp. paratuberculosis. Scand J Immunol 2001;53:198-203.

31 Shafran I, Piromalli C, Decker JW, et al. Seroreactivities against Saccharomyces cerevisae and Mycobacterium avium subsp. paratuberculosis p35 and p36 antigens in Crohn's disease patients. Dig Dis Sci 2002;47: 2079-2081.

32 Walmsley RS, Ibbotson JP, Chahal H, et al. Antibodies against Mycobacterium paratuberculosis in Crohn's disease. Q J Med 1996;89:217-221.

33 Swift GL, Srivastava ED, Stone R, et al. Controlled trial of anti-tuberculous chemotherapy for two years in Crohn's disease. Gut 1994;35:363-368.

34 Thomas GAO, Swift GL, Green JT, et al. Controlled trial of antituberculous chemotherapy in Crohn's disease: a five year follow up study. Gut 1998;42: 497-500. 